Article

\title{
What Does It Mean To Be a Badly Behaved Animal? An Answer from the Devadatta Stories of the Pāli Jātakas
}

\author{
Naomi Appleton $\mathbb{D}$ \\ School of Divinity, University of Edinburgh, Edinburgh EH1 2LX, UK; naomi.appletonl@ed.ac.uk
}

Received: 11 April 2019; Accepted: 19 April 2019; Published: 24 April 2019

\begin{abstract}
The many animals that appear in the Pāli Jātakatthavannanāa often mirror human predicaments, society and language, and this has prompted largely allegorical readings of the stories. In addition, in many cases the animals are identified as past lives of important human characters, potentially diminishing their animality further. In particular, the Buddha's repeated rebirth as a range of virtuous and wise animals tells us plenty about the Buddha, but arguably little about animals. Nonetheless, in this article I argue that the jātakas are able to tell us interesting things about the capabilities of animals. By using stories of another key animal character-namely Devadatta, the Buddha's nemesis-I explore what might be distinctive about the ability of animals to misbehave. Since Devadatta appears 28 times as an animal and 46 as a human, he allows us to probe whether or not the text's compilers saw a difference between human and animal capacities for evil. In the process, I raise questions about how we should view animal tales in the Jatakas more broadly, and highlight the productive tension between animals as unfortunate fellow travellers in the cycle of rebirth, and animals as literary devices that shed light on human behaviour.
\end{abstract}

Keywords: Buddhism; jātaka; Devadatta; animals; morality

\section{Introduction}

In scholarship about animal stories, a lot of debates centre around the question of whether such stories tell us anything about animals, or whether they are really just about humans. The hundreds of jātaka stories (stories of the past lives of the Buddha) that are found in the great Pāli Jätakatthavannana ${ }^{1}$ might be considered particularly poor sources of information about animals, since they often contain animals that appear to behave as humans, using language and modelling aspects of human society. Indeed, as (Harris 2006, p. 208) is quick to point out, in jätakas 'the animals are not really animals at all, for at the end of each story the Buddha reveals that the central character was none other than himself in a former life, with his monastic companions playing the supporting roles'. In other words, the knowledge that the main characters are famous humans depletes the ability of the tales to speak to us of "real" animals. We might note that a similar implication comes from an understanding that these animals were also human in a previous life; as (Jaini 2000, p. 255) notes in relation to similar stories in the Hindu epics, a narrative claim that animals were born such because of a human back-story 'reduces the relevancy of the tale as referring to animals and places the focus instead on a human being who was temporarily shackled by a lower destiny'. (Schmithausen and Maithrimurthi 2009, p. 100) sum up the

1 The Jātakatthavannanā ("Jātaka Commentary") is a large narrative collection in Pāli verse and prose. The verses are considered the word of the Buddha and included within the Khuddaka Nikāya of the Sutta Pitaka. There was doubtless always a prose narrative that circulated with these verses, but the final form of this dates to as late as the fifth or sixth century CE. $\mathrm{J}=$ Jätakatthavannanā, according to numbering in (Fausbøll 1877-1896) and (Cowell 1895-1907). 
position by commenting that '[i]n this genre of texts, animals are often used to represent humans, and at any rate are conceived of, or at least depicted, as being, feeling, and acting basically like humans. ${ }^{2}$

Reiko Ohnuma, in her 2017 volume on animals in Buddhism, helpfully moves beyond this animal-versus-human dichotomy to explore how the animality of animals is still important even in stories where they largely model human behaviour, or where they have been or will be reborn as humans (see especially pp. 48-50). Likewise, Christopher Key Chapple, while acknowledging that the animals of the jātakas 'are seen not so much as animals but as potential humans' (Chapple 1997, p. 143), also notes that they are 'animals that can teach humans a lesson' (p. 143) and that animals can be 'imaginative tools' (p. 132) for human reflection. In this paper, I, too, would like to move beyond seeing jātakas as being just about humans, and rather see how the allegorical and the animal are combined in a particular selection of Buddhist jätaka stories, namely those that characterise animals as villains.

The idea for this paper emerged from research I carried out for my 2014 book Narrating Karma and Rebirth, which includes a brief exploration of how animals feature in Buddhist and Jain multi-life stories. In amongst a discussion of how beings ended up reborn as animals, and how they managed to escape the animal realm again, I found myself fascinated by the very limited opportunities that animals appear to have to act morally, and thus to gain good karma. Ohnuma has since explained the situation more extensively in the opening chapter to her own recent monograph (Ohnuma 2017), at least for the Buddhist side of the equation. As we both note, animals are said in Buddhist texts to lack a particular sort of wisdom and thus moral capacity, limiting their ability to escape their realm of rebirth (Appleton 2014, pp. 22-43; Ohnuma 2017, pp. 5-23). Instead, animals are often said to be naturally bad, in that they spend their lives eating one another and committing incest. As a result of this terrible position, animals have limited opportunities to better their situation, and usually rely upon an experience of prasāda (Sanskrit)/pasāda (Pāli), or "faith" that comes about during an encounter with the/a Buddha. Such encounters are, of course, as rare as they are transformative.

Stories of the very limited opportunities that animals have to escape the bad realms of rebirth led me to ask: If animals are usually incapable of virtue, because of their deluded and instinctive nature, then what capacity do they have to do morally bad deeds, to make bad karma? Does that inevitably arise from living as an animal (as implied in some of the more philosophical discussions), and if so, then why do we so rarely find narratives that show animals being reborn in similar or worse situations as a result of their bad karma? Are animals as capable of evil as humans are, or are they more limited in their abilities? I addressed these questions briefly in my book, and wish to return to them here in this longer paper, with a particular focus on jätaka portrayals of "bad" animals.

As many will know, when we meet a "bad" animal in the jātakas, it often turns out to be Devadatta in a past life. Just as many jātaka tales purport to tell of the many and enduring virtues of the Buddha-to-be, so other characters also reveal traits that continue across multiple lifetimes. For example, Ānanda, the Buddha's favoured attendant, is often the Bodhisatta's friend or relation, and often displays the same gentle folly or ignorance with which he is portrayed in stories of his final life. Occasionally, Ānanda is female in a past life, in rare examples of sex-change between lifetimes, perhaps in some way linked to his closeness to the nuns' community or his emotional attachments to the Buddha. Sāriputta and Moggallāna are often friends of the Bodhisatta too, and usually wise. Sāriputta is said to have been stubborn and intransigent in multiple lifetimes. Uppallavaṇnā, famed for her attainment of supernatural powers in her final life, is often a goddess in the jätakas. And Devadatta, attempted murderer and schismatic monk, rival to the Buddha, is very often the villain.

Devadatta, then, offers an interesting case study in animal capabilities. Like the Buddha, who is (almost) always an extraordinarily virtuous animal, Devadatta is (almost) always the worst animal

2 As always it is worth paying attention to the differences we find across different genres or bodies of literature. For example, (Olivelle 2013) implies that animal stories are really just about humans, but he is mainly concerned with the Pañcatantra, where such a position is relatively easy to defend. This position is less easily defended, I would argue, when it comes to jātaka literature. 
you could imagine. As such, his behaviour should show us the limits of animals' capabilities for evil. In addition, as a character who appears multiple times in both animal and human births, Devadatta allows us to directly compare examples of human evil with examples of animal evil. A study of Devadatta thus raises some particularly interesting questions that bring us right back to the fundamental issue of how animal stories work: When Devadatta is a bad animal, is it a lesson about animals, or a lesson about humans, or a lesson about Devadatta in particular? The bigger question of whether animal stories are allegorical or not turns out to miss an angle, namely what happens when stories seem to be deliberately about an individual character with some special significance, who maintains certain traits even as he moves between realms of rebirth? ${ }^{3}$

What, ultimately, do stories of Devadatta's animal births tell us about animals in Buddhism? To answer this, I will first survey the jātakas of the Pāli Jātakatthavannnanā that feature Devadatta as an animal, and explore the key themes and traits that seem to be particularly associated with these stories. I will then ask how the characteristics and experiences of Devadatta-as-animal differ from those of Devadatta-as-human, before taking a step back to ask about the larger significance of these stories as stories that are at once about animals, about humans, and about one particular villain who moves between the human and animal realms.

\section{Devadatta as an Animal in the Jātakas}

According to my reckoning, Devadatta appears as an animal in 28 of the stories contained within the Jätakatthavannanāä; these are summarised in Appendix A.1 below. He appears as a human in a further 46 stories, and in two more as a divine being of some sort (also detailed in the Appendices A.2 and A.3 respectively). As such, his animal births account for a little over a third of Devadatta's overall appearances, yet they also contain some of the most famous and popular characterisations, for example in the three related stories of his attempts, as a crocodile, to gain the heart of a monkey (the Bodhisatta). These stories can be broadly clustered into six groups, according to the main theme or the characteristic being explored, though several stories bridge more than one theme:

\subsection{Devadatta Trying to Imitate the Bodhisatta, or Showing off in Error, Believing Himself To Be More Than He Is}

In these stories, Devadatta overestimates himself. In J143 and J335 he, born as a jackal, tries to act like his patron, a lion (the Bodhisatta), with disastrous results: he is trampled to death by his elephant-prey. Similarly, in J204 he tries diving for fish like his water-bird patron (the Bodhisatta) despite being a crow, hence quite the wrong type of bird for such activities; he drowns as a result. In J210 he imitates a woodpecker (the Bodhisatta) despite not being made for pecking wood, and as a result he breaks his beak. In J160, though only a scruffy mongrel of a flightless bird, he thinks himself a king because he is conveyed through the air by a pair of geese. In J168, he is so keen to show off his hunting prowess to a newly caught quail that he ends up losing not only his prey, but his life. In J241, he is a jackal who uses a spell to gather an army, only to be trampled to death by them, while in J294 and J295, also as a jackal, he offers unearned verses of praise to a crow, who praises him in return. In all these stories, Devadatta's arrogance and inflated sense of self lead to embarrassing, painful or even fatal consequences. Very often, his folly is contrasted directly with the true qualities of the Bodhisatta.

3 We might also ask: If the Bodhisatta is able to be a virtuous animal despite the lack of opportunities for virtue in ordinary animals, then can Devadatta be a "bad" animal, and does this likewise set him apart from other animals in the jātakas? Although a systematic comparison with other stories of "bad" animals is beyond the scope of this paper, my initial answer would be no, since we also find other stories of animals being deceitful and violent, though no other character is quite so consistently bad as Devadatta. 


\subsection{Devadatta Being a Bad Leader}

In these stories, Devadatta is shown to be a bad leader, causing danger to those in his care. In J11, his poor leadership as a deer leads to the loss of his herd, and this is contrasted with the good leadership of his brother, identified as Sāriputta. J12 also sees him in charge of a herd of deer, and here he famously refuses the entreaties of a pregnant doe whose turn it is to be given to the king's hunters. She instead has to take refuge with the leader of the other herd, who is of course the Bodhisatta, and who offers himself in her stead, thereby causing the king to reconsider his whole attachment to hunting. In J33, Devadatta is a quail who spreads dissent amongst the flock, leading them all to be captured, while in J404 he leads a troop of monkeys and, despite warnings, fails to protect them from danger. Once again, these stories all show Devadatta to have a wrongly inflated sense of his qualities, but here the dangerous consequences are not felt by Devadatta alone, but also by those foolish or unfortunate enough to follow him. And, once again, his bad leadership is often held up in direct contrast to the good leadership of the Bodhisatta or other senior monks.

\subsection{Devadatta Trying to Kill or Harm the Bodhisatta}

Perhaps the most famous stories of Devadatta-as-animal are those in which he tries to kill or harm the Bodhisatta in the form of another animal. In some cases, we see the predator-prey dynamics of the natural world coming into play, such as in the two stories in which Devadatta is a falcon pursuing smaller birds for food (J168, J448). In many cases, however, even a straightforward hunt has elements of deception, such as when, in the latter story, he tries to befriend his prey (J448) or when, as a chameleon (that embodiment of dissembling), he betrays his former friends to a hunter (J141). In three famous stories, or three versions of a famous story, Devadatta is a crocodile who befriends a monkey (the Bodhisatta) and then attempts to kill him in order to get his heart, which the crocodile's wife craves (J57, J208, J342). In J407, Devadatta is a monkey who breaks the Bodhisatta-monkey's back after the latter makes himself into a bridge to safety. (Intriguingly, Devadatta's identification with the bad monkey is made during the narrative, and not in the identification of births at the end of the story.) The betrayal of friends, or false friendship, seems therefore to be a key theme in these stories, and there are also betrayals of family duty, such as in the story of Devadatta as the leader of a troop of monkeys who castrates his sons by ripping out their testicles with his teeth, in order to prevent rivals, and attempts to kill the Bodhisatta after he escapes this procedure (J58). To further emphasise this point, true friendship sometimes preserves the Bodhisatta: in J389, Devadatta-as-crow tries to fetch the Bodhisatta's eyes for his wife, but the Bodhisatta (a brahmin) is protected by a crab (Ānanda) who has become his friend.

Although Devadatta's actions are clearly portrayed as wrong in these stories, it is the particular act of betrayal that seems most often to be highlighted. In other words, the point is not simply that Devadatta has always been murderous, but that he has always sought to harm the Bodhisatta in particular, despite the latter's kindness towards him. Just one story shows Devadatta's cruelty directed more generally: In J357, he is an elephant who destroys a nest of baby quails all just because he can; their mother eventually enacts her revenge with the help of a group of unlikely animals. While the frame narrative tells us that this is a story about Devadatta being completely pitiless, the verse seems rather to imply that the story illustrates the power of working together.

\subsection{Devadatta Displaying Ingratitude towards the Buddha}

Several of the stories already explored demonstrate another key trait of Devadatta, namely ingratitude to the Bodhisatta. For example, in the story of the monkey just discussed (J407), Devadatta attacks the very being who has just saved his life, while in several lifetimes discussed above (J143, J204, $\mathrm{J} 210$, J335), he cannot seem to bear being supported by the generosity of a superior animal, and so responds by attempting to imitate them, with disastrous results. In some stories, this ingratitude is the primary theme, most obviously J308, in which Bodhisatta-as-woodpecker helps Devadatta-as-lion by 
removing a stick from his throat, yet when the woodpecker needs help later the lion is unwilling to return the favour. J174 is a rather more amusing and harmless exploration of this theme: Devadatta is a thirsty monkey, and after a kindly brahmin (the Bodhisatta) draws him some water from a well, the monkey's response is to pull faces at him!

\subsection{Devadatta Being Generally a Bit Foolish and Ridiculous}

The story of the monkey pulling faces (J174) leads us to another key theme that appears frequently in these stories and can be said to be the main concern of two, namely Devadatta's idiocy. In J113, Devadatta is a jackal who gets drunk and passes out, then tricks a friendly brahmin into smuggling him to safety, only to defecate on the brahmin's robe and run off. In J329, as a monkey, Devadatta becomes the king's pet, only to scare his children and be sent away. These stories make the most of the association between animals and mischief, poking fun at Devadatta as well as the people silly enough to be taken in by him.

\subsection{Devadatta Shown To Be Bad Company, or Affected by Bad Company}

The final theme to emerge from the stories is the idea of bad company. In J397, the emphasis is on Devadatta being bad company: he is a jackal who persuades his friend, a young lion, to kill the king's horses, leading to the death of the lion at the hands of the king. The lion's father (the Bodhisatta) explains that this was all the result of his son keeping bad company. Likewise, the story of the chameleon noted above (J141) is told to explain the results of the lizards keeping bad company. The effects of bad company on Devadatta himself are explored in J503, in which Devadatta is a parrot, whose brother is the Bodhisatta. When they are both young, the brothers are blown to different places: the Bodhisatta grows up amongst sages, and Devadatta amongst robbers. The different results are then explored in the story that ensues, but the message is an intriguing one: Are we to conclude that Devadatta is only bad because he has repeatedly kept bad company?

The six themes that I have outlined here could of course be separated out in different ways, and in many cases the overlapping nature of the themes is demonstrated by the fact that the same story fits into several categories. However, exploring the stories of Devadatta's births as animals under these headings allows us to appreciate the many echoes between Devadatta's multiple lifetimes: The themes are quite clearly related to Devadatta's actions during the final lifetime of the Buddha, when he wishes to take over the leadership of the sangha, claiming a level of attainment that he does not have (A), leads his followers towards hell (B), tries to have the Buddha killed (C), acting without proper gratitude for the teachings he has received from the Buddha (D), exposing himself thereby as a fool (E) and causing problems for those who keep company with him (F). Indeed, in most cases, the frame narrative makes explicit this link, by situating the Buddha's telling of the tale within a discussion of a particular transgression by Devadatta. None of this is particularly surprising, of course, for jätakas often work by mirroring events in the "present" time of the frame narrative, offering an echo of events that suggests a tiresome repetition of actions across multiple lifetimes. Devadatta's negative characteristics are thereby shown to be long-lasting habits, and his hostility towards the Buddha has followed him through countless rebirths.

This apparent continuity in Devadatta's traits and experiences encourages us not only to compare these animal births with his lifetime as the Buddha's cousin, but also to compare them with his other past lives, as humans. We might ask, are the themes identified here also found in his human lifetimes, or is there something distinctive about his characterisation as an animal that might reveal something about animals or animal stories more generally?

\section{Devadatta as Human and Animal: A Comparison}

We can see plenty of similarities when we compare these animal portrayals of Devadatta with jātakas in which he features as a human. We find stories of his ingratitude (J72, J73, J131, J193, J445, 
$\mathrm{J} 482, \mathrm{~J} 516$ ) and bad leadership (J1, J466), as well as a tale warning us of the dangers of keeping bad company (J184). Most common of all is the theme of Devadatta's multiple attempts on the Bodhisatta's life (J21, J72, J73, J122, J142, J193， J194， J206， J220， J221， J222， J277， J313， J358， J416， J438， J472， J482， J514， J516, J542). However, we also find some new character traits, including more sophisticated forms of deceit, as well as a different portrayal of the consequences of his actions.

As a human, Devadatta is often deceitful and greedy, in ways that are not out-of-line with his animal births, but which amplify the particular moral transgressions of human living. For example, in $\mathrm{J} 3$ he is a greedy merchant who lies to a woman about the real worth of her golden bowl, hoping to get it for a bargain price. Unfortunately for him, a rival merchant (the Bodhisatta) gives the woman a fair price for it, leaving Devadatta to die of anger. Devadatta often deceives others, particularly-it would seem-when he is a minister or ascetic. (This may also tell us something interesting about attitudes towards these characters-who are usually brahmins-in the jätakas, but that is another story.) As a minister, he betrays the king (J51), takes bribes when settling cases (J220, J542), and convinces the king to visit false teachers (J544) or to sacrifice humans in order to gain heaven (J542). As a sham ascetic, he eats meat and kills animals (J277, J438, J492) and tries to divide a king from his son (J505). In J336, Devadatta is a brahmin bold enough to lie to the gods about his qualities, and in J474 he lies in order to deny that the Bodhisatta was his teacher. Devadatta's association with lying is so strong that in two stories we see him literally sinking into the earth as a result (J422, J518).

This lying and deception take on new significance in stories about Devadatta-as-human interacting with animals. It is notable that in 17 stories of his human births (more than one-third of the total) Devadatta attacks animals, as a hunter (J21, J72, J206, J222, J514), fisherman (J139), fowler (J209), snake charmer (J506, J543), merchant (J482), king (J122), drunkard (J142), brahmin (J516), false ascetic (J277, J438, J492) or even a man disguised as a paccekabuddha (J221). Several stories are linked to the familiar theme of ingratitude, as Devadatta attacks an animal who has saved his life (J72, J482, J516). Many others also show Devadatta deceiving the animals—or attempting to do so-either through disguise or outright lies. This culminates in J222, when Bodhisatta-as-monkey offers himself to Devadatta-as-hunter in return for his promise not to harm his mother or brother. Not only does Devadatta merrily kill that monkey, he promptly breaks his promise by killing the rest of the family too. Such stories not only demonstrate Devadatta's inherent violence, and his lack of compassion for beings who rely upon him, but also the untrustworthiness of human promises.

Given that Devadatta is so consistently horrible, we might reasonably look for signs of the karmic consequences of his deeds in the stories, yet we find few. Concern about his repeated birth in happy circumstances is raised in the Milindapañha, where the royal interlocutor King Milinda is troubled that Devadatta appears to get away with his bad behaviour. As he points out, there are multiple lifetimes in which Devadatta has been born in a position superior to, or at least on a par with, the Bodhisatta, which suggests that good and bad deeds bear the same fruit. The Buddhist monk Nāgasena's response is that there are many other lifetimes not recounted in which he did good deeds, and also in which he suffered the consequences of his bad deeds. ${ }^{4}$ Though logically plausible, the explanation seems somewhat weak when we meet such an impressive consistency of bad behaviour in the jätakas, with little sense of the karmic consequences.

And it is in the consequences of Devadatta's actions that we see another difference between his animal and human births. As we saw in his animal births, Devadatta does often experience his comeuppance within his lifetime. He is trampled to death by elephants, drowns, breaks his beak, or is killed by those he has tried to harm. Significantly, however, the negative consequences are immediate rather than promised in the future. In none of Devadatta's lives as an animal do we witness him entering hell, nor even receive a firm indication that this will be his destiny.

4 For a discussion of the Milindapañha questions relating to jätakas see (Appleton 2010, pp. 69-71). This particular discussion is Meṇdakapañha IV, 7: Devadattassajātiyo according to the titles/divisions of (Trenckner 1962). 
That Devadatta-as-animal is never explicitly consigned to a hellish rebirth is doubly intriguing when we note that his human appearances in the jätakas meet that fate several times: In J72, for example, Devadatta is an ungrateful hunter who harms a white elephant (the Bodhisatta) who has saved his life. The great earth opens up and the flames of the Avīci hell envelop him and drag him downwards. In J313, the flames of the Avīci hell likewise leap out of the earth to ensnare him after he has mutilated the Bodhisatta-ascetic, and in J516 his betrayal of a monkey who has just saved his life sends him straight to hell. This even happens to him on the one occasion when he is reborn as a god: In J457, he is named Adhamma and teaches (surprisingly enough) adhamma or unrighteousness/immorality. After a showdown with the god Dhamma (the Bodhisatta), he plunges straight into hell.

Devadatta's consignment to hell in such stories is immediate, rather than simply being a promised afterlife destiny, and this is surely important to the narrative structure here. In J222, it is combined with other forms of immediate poetic justice: After Devadatta kills a monkey and his elderly mother and brother, despite promising not to, his own family is killed in a fire caused by a lightning strike. The house falls down on his head and the earth breaks open to swallow him into hell. In many other stories, we see this immediate comeuppance without any mention of hell. For example, in J194 Devadatta has ordered the Bodhisatta's execution, but the god Sakka intervenes and swaps them over at the last minute, leaving Devadatta to face his own executioner. These stories demonstrate a mixture of immediate and later consequences, yet it is nonetheless important that hell is one of the possible destinies facing a human past-life of Devadatta, whereas it is not presented as a possible destiny for an animal past-life of Devadatta.

It seems likely, given the patterns of behaviour we have seen in these stories, that the idea that animals do not go to hell is related in some way to their inability to lie. Indeed, an explicit link between lying and hell is made in J422, in which Devadatta is a king whose repeated lies lead him to sink further and further into the earth. On the seventh repetition of his lie the earth opens up completely and the flames of the Avīci hell come to claim him. In the same story, the Bodhisatta (in the form of the sage Kapila) repeatedly praises the virtues of telling the truth, and warns the king of the terrible consequences of breaking with truth and dhamma. That lying is one of the worst possible things to do is a message repeated in J431, in which the Bodhisatta considers lying to cover up his affair with a king's wife, but decides not to, because truth is the ultimate support. As the commentary goes on to tell us, while the Bodhisatta does sometimes kill, commit sexual impropriety, get drunk and steal, he cannot lie. ${ }^{5}$ There is something particularly awful about lying, presumably linked to its breaching of dhamma as the Truth. ${ }^{6}$ As such, lying can and does lead to hell.

While this all makes sense in a human realm, it does not seem to be the case that animals lie anything like as frequently or severely as humans. As an animal, Devadatta often betrays, but examples of sophisticated deceit are rare. As a crocodile, he attempts to deceive but is outwitted by the lies of the monkey-Bodhisatta (J57, J208, J342), preventing us from judging him harshly for this. In J448, he pretends to be a friend, but not with any elaborate disguise; even in the story of the chameleon (J141) he betrays what starts as a genuine friendship, rather than dissembling from the start. In the vast majority of his animal births, Devadatta's deeds are not devious but just straightforwardly stupid or nasty. We seem, therefore, to be learning that deceit and deviousness are traits not associated with animals. $^{7}$

5 See discussion in (Appleton 2010, pp. 29-32).

6 This position is of course strengthened by the fact that a sincere utterance of the truth (or "truth-act", saccakiriya) can forcefully change one's circumstances for the better.

7 As the Kandaraka Sutta (Majjhima Nikāya 51) tells us, animals are fairly straightforward, whereas humans are a tangle of corruption and deceit. (My thanks to Phyllis Granoff for bringing this reference to my attention.) We must be cautious on this point, however, since there are other stories about animals that are not identified with Devadatta. One particularly famous tale, the Bilāra-jātaka (Jātakatthavannanā 128), portrays a cat/jackal as a false ascetic who eats his mouse-followers one-by-one, in a clear parallel to stories of humans pretending to be ascetics, and a definite display of deceit; notably, the villain here is not identified as Devadatta. 
While we might note that lying requires language, and animals do not have language, this would not help as an explanation in the world of the jātakas, where animals commonly speak. As Ohnuma notes, animal speech is often used to comment on how humans are more beastly than beasts: 'The animals of the jātakas may be able to speak-but only so that they can tell us that human promises are empty' (Ohnuma 2017, p. 57). We are perhaps led to the conclusion that animals do not tell lies not because they lack speech, but because they lack the mental capacity to deceive. Indeed, we need here to bring in the other major contrast between Devadatta-as-animal and Devadatta-as-human: the former is very often a total idiot, completely deluded about his capabilities, while the latter is often devious, manipulative and scheming, as well as violent. As such, while the desire to harm or usurp others is a steady character trait, the tools available for accomplishing this vary between animal and human lifetimes.

\section{Concluding Thoughts}

This discussion of Devadatta's characterisation brings us back to the question of how animals are used to teach us about humans. As Daston and Mitman (2005, p. 9) note, fables often involve humanising animals by caricaturing them: 'Whereas the same stories told about humans might lose the moral in a clutter of individuating detail of the sort we are usually keen to know about other people, substituting animals as actors strips the characterizations down to prototypes.' This assessment would appear to be largely true of Devadatta's various appearances in the jātakas: he is caricatured as the prototypical villain, in part though identification with villainous animals, such as falcons, crocodiles and jackals, and in part through repeated deeds, such as attempting to kill or usurp the Bodhisatta. However, these stories also tell us about Devadatta as an individual. His "villainy" directly reflects his acts at the time of the Buddha, suggesting a continuity of traits and relationships across multiple lives. To an extent, the reverse of Daston and Mitman's suggestion is therefore taking place: the audience's knowledge of the 'clutter of individuating detail' about Devadatta as a human affects their response to his behaviour as an animal. So are these stories about Devadatta, about animals, or about humans? I would suggest that we ought to pay attention to all three of these angles.

I have argued in this paper that we might most helpfully understand stories of Devadatta-as-animal by reading them alongside stories of Devadatta-as-human. By so doing, however, we need to avoid simplistic labelling of all the stories as exhibiting the same "human" traits-those we associate with Devadatta at the time of the Buddha-though this is certainly true to an extent. Importantly, reading the stories alongside one another reveals that the particular acts Devadatta carries out as an animal differ from those he tends towards as a human. This may therefore tell us something about broader perceptions of animal capabilities: Whereas "bad" humans are those who lie and break their word, as well as attack and torture and kill, "bad" animals are presented as straightforwardly violent or stupid, unable to dissemble in complex ways. And, while really bad humans might enter hell straight away, bad animals meet this-worldly comeuppance, implying they may not be capable of the carefully considered deception and violence that lead one directly to hell. ${ }^{8}$

It is of course debateable how far we should generalise the stories of Devadatta in particular. After all, as the Buddha's nemesis, his consistent villainy is as unsurprising as the Bodhisatta's consistent virtue. Yet even here Devadatta surprises us, outdoing the Bodhisatta in his consistency. The Bodhisatta has many lapses, gambling and womanising and even killing. ${ }^{9}$ Devadatta, by contrast, only once suggests he might regret his chosen path of bad behaviour: In J472, he is a king who attempts to kill his own son by having him thrown off a cliff, but later meets him again (he was saved by a deity) and

8 (Ohnuma 2017, pp. 20-21) discusses the inability of animals to perform the five most appalling transgressions, which lead immediately to hell. These worst-possible deeds are of course only one subset of deeds that lead to hell.

9 I discuss some of the many exceptions to the Bodhisatta's virtuous presentation in (Appleton 2010, chp. 2). 
repents and reforms, living righteously thereafter. (Notably, Devadatta is not actually mentioned in the frame story for this tale, so no connection is made with his "present" character's capacity for reform. $)^{10}$

This one act of repentance aside, the stories of Devadatta leave us with a disturbing sense of the endurance of moral habits and desires, especially negative ones, which are shown as pursuing Devadatta across rebirth realms with no sign of abatement. Despite this consistency, however, these stories also highlight the far greater capacity that humans have for violence and deceit in comparison with animals. Even the worst animal of all—Devadatta-as-animal—cannot rival Devadatta-as-human when it comes to cruelty or deceit, though he might give him some competition in his folly.

Funding: This research received no external funding.

Acknowledgments: I would like to thank the organisers and participants at the "Buddhist Beasts" Conference at UBC in April 2018, the Glorisun foundation for their financial support of the event, and the editors of this collection of papers, Reiko Ohnuma and Barbara Ambros, for their careful comments and suggestions.

Conflicts of Interest: The author declares no conflicts of interest.

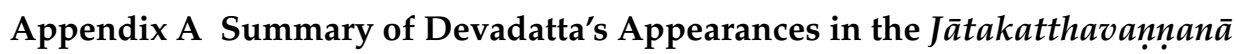

\section{Appendix A.1 Animal Births}

J11 Deer who leads herd to disaster, in contrast to brother's herd; Bodhisatta their father.

J12 Deer king who ignores pleas of pregnant doe who is due to die; the leader of the other herd (the

J12 Bodhisatta) offers himself in her stead.

J33 Quail who foments discord that causes the whole flock to be unable to escape a fowler.

J57 Crocodile who tries to catch a monkey (the Bodhisatta) to get his heart, but is outwitted.

J58 Monkey king who violently castrates his sons to prevent rivals, but one (the Bodhisatta) escapes.

J113 Jackal who gets drunk and tricks a brahmin into smuggling to safety, then defecates on his robe.

J141 Chameleon who forms a friendship with lizards then plots with a hunter to kill them all.

J143 Jackal who arrogantly imitates his patron, a lion (the Bodhisatta), by hunting an elephant, and is trampled to death.

J160 Bird who thinks himself to be like a king (the Bodhisatta), despite being a cross-breed flightless bird transported by geese.

J168 Falcon who catches a quail (the Bodhisatta) then lets him go in order to demonstrate his hunting prowess, but dies on second attempt.

J174 Monkey who ungratefully pulls faces at a brahmin (the Bodhisatta) who has provided him with water.

J204 Crow who, not happy being supported by a water-bird (the Bodhisatta), arrogantly decides to fish for himself, and drowns.

J208 As J57.

J210 Bird who, not happy being supported by a woodpecker (the Bodhisatta), arrogantly decides to peck for his own insects, and breaks his beak.

J241 Jackal who overhears a spell belonging to a brahmin (the Bodhisatta) and uses it to gather an army, but is then trampled to death by them.

J294 Jackal who flatters a crow, who flatters him back; a tree-deity (the Bodhisatta) frightens them off.

J295 As J294.

J308 Lion who is saved from a stick in the throat by a woodpecker (the Bodhisatta), but later refuses to help in return.

J329 Monkey who briefly gains the favour of the king, but then scares his children and is sent away.

J335 As J143.

$\mathrm{J} 342 \quad$ As J208 and J57.

10 This story is presented as being about Ciñcamānavikā's attempt to discredit the Buddha: she is the queen who maligns the prince to his father. It is notable that the identification of Devadatta is in verse (as a significant minority of identifications are presented); this might potentially have made it harder to adjust or remove later once his villainy became considered immovable. 
Elephant who deliberately kills baby quails despite their mother's entreaty. Mother quail teams up with other animals to torture and kill him.

J389 Crow who tries to attack brahmin (the Bodhisatta) but ends up killed by a crab who is the brahmin's friend.

J397 Jackal who persuades a lion to kill the king's horse, leading to the lion's death. Lion's father (the Bodhisatta) explains it is because his son kept bad company.

J404 Monkey whose troop is told to leave (by the Bodhisatta) because of danger from humans, but they stay and are killed.

$\mathrm{J} 407$

Monkey who breaks the back of the leader of the troop (the Bodhisatta) while the latter is making his body into a bridge to safety for all the monkeys. (Note: Not named in samodhāna.)

Falcon who tries to befriend a bird (the Bodhisatta) after eating all his friends, but the bird is not fooled.

Parrot who grows up amongst robbers so is bad, in contrast to brother (Bodhisatta) who grows up amongst sages.

\section{Appendix A.2 Human Births}

J1 Foolish merchant who leads his men to disaster.

J3 Greedy merchant who fails to get golden dish, and dies of anger.

J21 Hunter who tries to kill a deer (the Bodhisatta).

J51 Minister who tries to help rival king usurp Bodhisatta's throne.

J72 Hunter who attacks the elephant who saved his life (and taken to hell).

J73 King who orders the execution of a hermit (the Bodhisatta) who had saved his life.

J122 King who tortures an elephant (the Bodhisatta) out of jealousy.

J131 Treasurer who refuses to help his friend (the Bodhisatta) who previously helped him.

Fisherman who loses his sight and his clothes, and his wife is beaten, all through folly and greed.

J142 Drunken rogue who plays dead in an attempt to catch a jackal to eat.

J184 Horse-trainer whose horse imitates his lameness, demonstrating the effects of keeping bad company.

J194 King who tries to have the Bodhisatta killed so he can steal his wife.

J206 Hunter who is outwitted by a woodpecker, tortoise and deer (the Bodhisatta).

J209 Fowler who can't catch a bird.

J220 Judge who takes bribes and tries to have the Bodhisatta killed. King who orders a sage (the Bodhisatta) to be mutilated (and consequently enters hell). 
J514 Hunter who kills a mighty six-tusked elephant (the Bodhisatta).

J516 Brahmin who tries to kill a monkey (the Bodhisatta) who has just saved his life (and is swallowed into hell as a result).

J518 Ascetic who betrays a $n \bar{a} g a$, tells lies and sinks into the earth.

J542 Brahmin who tries to have a prince (the Bodhisatta) killed in a sacrifice.

J543 Snake charmer who captures a virtuous nāga (the Bodhisatta).

J544 Minister who advises king to visit fatalist ascetic, to the detriment of the kingdom.

J546 Minister to a king, rival to the wise Mahosadha (the Bodhisatta).

J547 Jüjaka, the greedy old brahmin who requests the children of Vessantara (the Bodhisatta) as slaves.

\section{Appendix A.3 Other births}

J20 Water-demon who attacks monkeys but is outwitted by their leader (the Bodhisatta).

J457 God called Adhamma who teaches adhamma, meets Dhamma-god (the Bodhisatta) and after an exchange plunges straight into hell.

\section{References and Note}

Appleton, Naomi. 2010. Jātaka Stories in Theravāda Buddhism: Narrating the Bodhisatta Path. Farnham: Ashgate.

Appleton, Naomi. 2014. Narrating Karma and Rebirth: Buddhist and Jain Multi-life Stories. Cambridge: Cambridge University Press.

Chapple, Christopher Key. 1997. Animals and Environment in the Buddhist Birth Stories. In Buddhism and Ecology: The Interconnection of Dharma and Deeds. Edited by Mary Evelyn Tucker and Duncan Ryūken Williams. Cambridge: Harvard University Press, pp. 131-48.

Cowell, Edward Byles, ed. 1895-1907. The Jātaka, or Stories of the Buddha's Former Births. Several Translators. vol. 6, Cambridge: Cambridge University Press.

Daston, Lorraine, and Gregg Mitman, eds. 2005. Thinking with Animals: New Perspectives on Anthropomorphism. New York: Columbia University Press.

Fausbøll, Viggo, ed. 1877-1896. The Jātaka Together with its Commentary Being Tales of the Anterior Births of Gotama Buddha. vol. 6, London: Trübner and co.

Harris, Ian. 2006. A vast unsupervised recycling plant: Animals and the Buddhist Cosmos. In A Communion of Subjects: Animals in Religion, Science and Ethics. Edited by Paul Waldau and Kimberley Patton. New York: Columbia University Press, pp. 207-17.

Jaini, Padmanabh S. 2000. Indian Perspectives on the Spirituality of Animals. In Collected Papers on Jaini Studies. Delhi: Motilal Banarsidass, pp. 253-66.

Ohnuma, Reiko. 2017. Unfortunate Destiny: Animals in the Indian Buddhist Imagination. New York: Oxford University Press.

Olivelle, Patrick. 2013. Talking Animals: Explorations in an Indian Literary Genre. In Charming Beauties and Frightful Beasts: Non-Human Animals in South Asian Myth, Ritual and Folklore. Edited by Fabrizo M. Ferrari and Thomas Dähnhardt. Sheffield: Equinox, pp. 3-14.

Schmithausen, Lambert, and Mudagamuwe Maithrimurthi. 2009. Attitudes towards Animals in Indian Buddhism. In Penser, dire et représenter l'animal dans le monde indien. Edited by Nalini Balbir and Georges-Jean Pinault. Paris: Librarie Honoré Champion, pp. 47-121.

Trenckner, V., ed. 1962. The Milindapañho. London: The Pali Text Society.

(C) 2019 by the author. Licensee MDPI, Basel, Switzerland. This article is an open access article distributed under the terms and conditions of the Creative Commons Attribution (CC BY) license (http://creativecommons.org/licenses/by/4.0/). 